\title{
SUSTAINING AND SUBSTITUTING THE SACRED: COIN TREES IN BRITAIN AND IRELAND
}

\author{
Ceri Houlbrook \\ Lecturer in Folklore and History \\ University of Hertfordshire, United Kingdom \\ c.houlbrook@herts.ac.uk
}

\begin{abstract}
It is the character of a natural holy place to shift and alter. Sometimes the changes are the product of natural causes; other times, they are the result of human intervention. The mutable character of these natural sites, however, does not impair their ability to act as holy sites; instead, it appears to benefit them, for just as nature is not static, neither is the 'sacred'. In order to explore how appropriate natural sites are as 'settings' for the 'sacred' because of their very mutability, this paper will focus on coin-trees. These are natural places of pilgrimage in Britain and Ireland, which have sustained themselves as sacred centres for decades - in some cases, centuries - and have, during that time, undergone numerous recontextualisations, adapting themselves to the religious and cultural changes of their surroundings.
\end{abstract}

Keywords: Britain, Christian saints, coin-trees, holy wells, Ireland, sacred

\section{INTRODUCTION}

It is the character of a natural holy place to shift and alter; natural environments, subject to organic processes, undergo constant change. Sometimes they are small and barely discernible: the slow growth of a tree or a slight change in the depth of a holy spring. At other times, they are drastic and hard to miss: the felling of a grove of trees or the destruction caused by a flood. Sometimes they are purely the product of natural causes; at other times, the result of human intervention. Either way, change is inevitable.

The mutable character of these natural sites, however, does not impair their ability to act as sacred sites; instead, it appears to benefit them, for just as nature is not static, neither is the sacred. Defined as that which is "dedicated, set apart, exclusively appropriated to some person or some special purpose" (OED 2019b), the 'sacred' is used here heterogeneously to mean sites that are 
perceived as 'special', but not necessarily through religious association. On the other hand, the 'holy', which is defined as being "appropriated or set apart for religious use or observance" (OED 2019a), is applied in this paper to sites and structures that have been explicitly linked to Christianity.

In order to illustrate how appropriate natural sites are as 'settings' for the 'sacred' because of their very mutability, this paper will focus on natural places of pilgrimage in Britain and Ireland, which have sustained themselves as sacred centres for centuries and have, during that time, undergone numerous recontextualisations, adapting themselves to the religious and cultural changes of their surroundings. However, because of the vast number and variety of natural pilgrimage sites in Britain and Ireland, this paper focuses on one particular type: those containing coin trees that are still active today. In order to contextualise these contemporary coin trees, the sites' histories are traced, revealing long discourses of ritual adaptation.

\section{COIN TREES: AN INTRODUCTION}

As this paper is not intended as a study of the coin tree itself, but rather employs it as a micro-historic exemplar in an exploration of how natural 'sacred' sites change over time, only a necessarily brief summary of the practice is supplied (see Houlbrook 2014, 2015, 2018a, 2018b for more detailed considerations).

Coin trees are exactly what the name would suggest: trees (often logs) which have coins embedded edgeways into their bark. Thus far, 40 sites containing over 200 coin trees have been catalogued, distributed widely across England, Wales, Scotland, Northern Ireland, and the Republic of Ireland. These sites are often in rural areas accessible to the public, situated alongside popular woodland or riverside footpaths. Of the 40 sites, 37 are 'active', insofar as people today continue to participate in the custom of inserting coins into the trees. During fieldwork conducted in 2011-2013, all coins deposited into/on coin trees at 31 of the sites were catalogued, reaching a total of 165,360. Fieldwork and archival research discovered that the majority of coin trees are contemporary, dating to the late twentieth or twenty-first century; the possible reasons behind this modern-day surge have been explored by Houlbrook (2018a). Some coin-trees, however, did prove to be historic.

The earliest known coin tree is an uprooted oak on Isle Maree, a small island in Loch Maree in the Northwest Highlands of Scotland (Fig. 1). The first reference to deposits at this site comes from Thomas Pennant's 1775 A tour in Scotland and voyage to the Hebrides, in which he describes the island's holy well, said to have been consecrated by Saint Maelrubha - also known as Saint 
Maree - in the eighth century and widely believed to cure insanity. Beside the holy well was a tree, which was utilised as an 'altar'; pilgrims who sought a cure from the well would leave their tokens of thanks to Saint Maelrubha on this particular tree (Pennant 1775: 330).

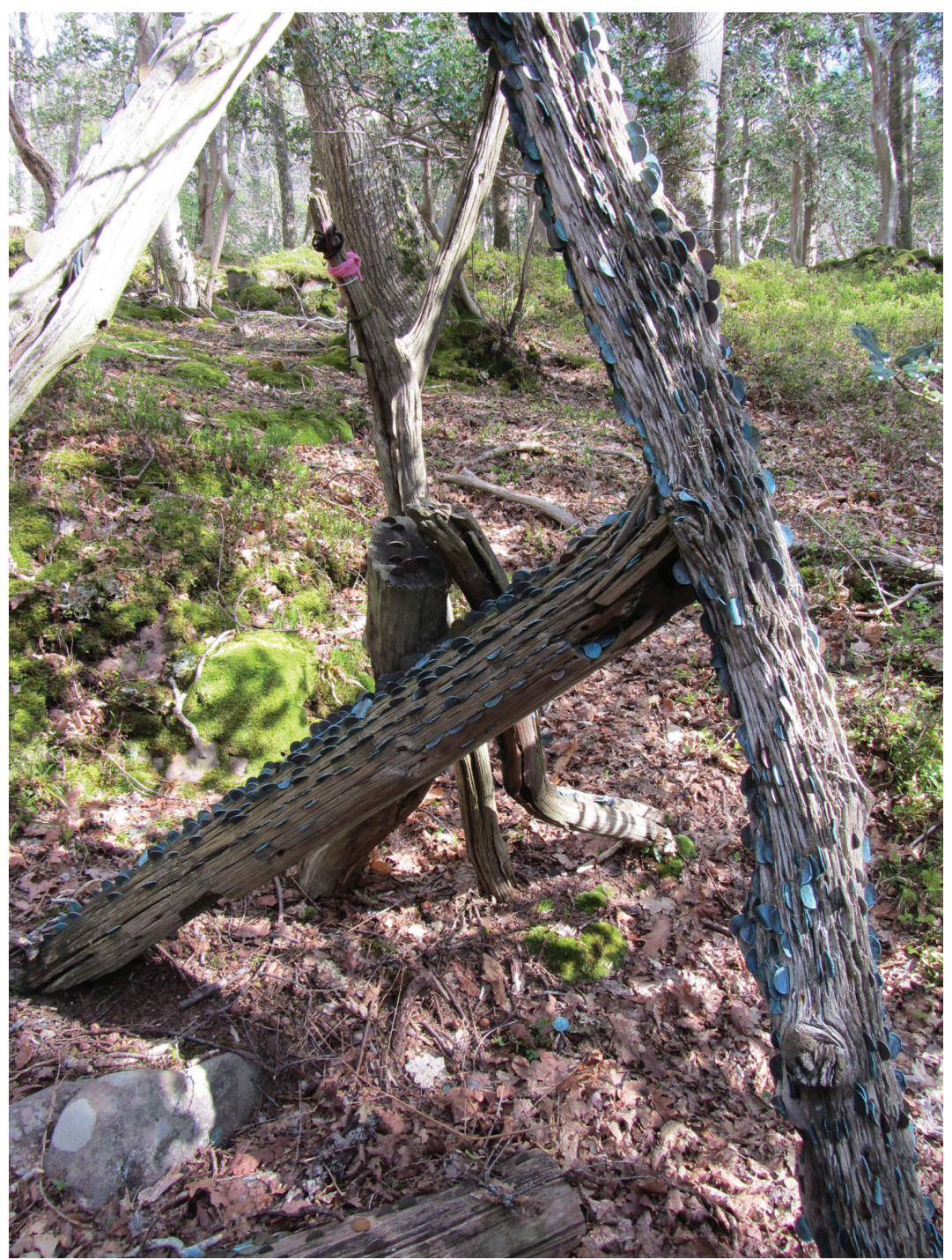

Figure 1. The coin tree on Isle Maree, Northwest Highlands of Scotland. Photograph by the author, 14 April 2012. 
According to the Inverness Courier of 4 November 1852, cited by Reeves (18571860: 288-289), the well was believed to have lost its curative powers when a farmer brought his dog to the island and lowered it into the well, hoping to cure it of madness. Dixon writes that this "desecrating act is said to have driven virtue for a time from the well" (1984 [1886]: 157). The curative powers of the well were thus believed compromised, and by the $1860 \mathrm{~s}$, it was no longer resorted to for the cure of insanity. By the time Mitchell visited Isle Maree in 1863, the well was dry "and full of last year's leaves, and the flat stone which serves for a cover we found lying on the bank" (1860-1862: 262). Today no visible trace remains of either the well or its stone slab covering - but the tree, described by Pennant in 1775 as the 'altar' on which pilgrims left their tokens of thanks, still just about stands.

According to Pennant's wording, the tree was incidental to the custom; it was simply a convenient structure in close proximity to the well. In many cases, however, trees do appear to have developed more significance. Indeed, numerous holy wells were named after trees, such as 'Ash well', 'Holly well', and 'Oak well', and in some cases, the trees do seem to have been essential to the efficacy of the wells. At Easter Rarichie, Ross and Cromarty, for example, there was a well believed to cure tuberculosis so long as a certain tree stood beside it. When this tree was felled, the well purportedly lost its power; the same occurred when two trees fell beside a well near Perth in 1770 (Bord \& Bord 1985: $59,101)$. Trees are often believed integral to this custom due to the protection they offer. Trees were often utilised as apotropaic devices, and several different species, most notably ash, were believed to function as protective agents in the early modern period, planted beside wells as guardians to ward off fairies and witches (Hope 1893: xxii; Hull 1928: 113; Shepherd 1994: 2, 63; Rackard \& O'Callaghan \& Joyce 2001: 8). Whether or not this was the origin of the tree on Isle Maree, it certainly developed greater significance than as a convenient altar. It appears to have replaced the well as a pilgrimage destination.

Trees standing beside holy wells often partake in their sanctity (Lucas 1963: 40). In some cases, the water is believed to have physically transferred from the well to the tree. This transference of sanctity from water to tree not only imbues the latter with power, but allows it to establish itself as a ritual structure independent of the holy well, so that it might subsequently outlive it. In other cases, the transferal is symbolic, with the tree developing sacredness as the well loses it. This is what appears to have happened with what would later become the Isle Maree coin tree.

Initially, the tokens left on this tree appear to have been rags (strips of cloth also known as clooties), which were common votive offerings. However, during the nineteenth century, pilgrims began leaving other objects such as 
nails and pins (Campbell 1860: 134; Mitchell 1860-1862: 253). These metallic objects had originally been employed to hold the rags in place on the tree, but had gradually become offerings in and of themselves (Dixon 1984 [1886]: 152). By the late nineteenth century they appear to have been replaced by coins.

In 1877 the site received a famous visitor: Queen Victoria, who travelled to Isle Maree on a tour of Scotland. She and her party embedded some coins into the tree themselves, although by this point the coin was simply viewed as an offering to St Maelrubha rather than as a bid for the cure of insanity. Queen Victoria described the tree in her diary, in an entry dated 17 September 1877, as follows:

The boat was pushed onshore, and we scrambled out and walked through the tangled underwood and thicket of oak, holly, beech, etc., which covers the islet, to the well, now nearly dry which is said to be celebrated for the cure of insanity. An old tree stands close to it, and into the bark of this it is the custom, from time immemorial, for everyone who goes there to insert with a hammer a copper coin, as a sort of offering to the saint who lived there in the eighth century, ... We hammered some pennies into the tree. (Duff 1968: 332-333)

Queen Victoria referred to the coin as a "sort of offering to the saint", showing how the tree had maintained its Christian associations. However, with the loosening grip of the Church and the declining faith in the power of saints and their holy wells, traditions needed to adapt in order to retain their popularity.

By the late nineteenth century, the tree's purpose had changed. It had become a "wishing tree", a term employed by Dixon (1984 [1886]: 150), Godden (1893: 499), McPherson (2003 [1929]: 76), Barnett (1930: 114), and Macrow (1953: 88-89). It was now believed that, in McPherson's words, a "wish silently formed when any metal article was attached to the tree, or coin driven in, would certainly be realised" (2003 [1929]: 76). No longer associated with healing, the tree had become imbued with the power to grant wishes or ensure good luck (MacLeish 1968: 420), the only two traditions which participants seem familiar with today. Local residents in the nearby town of Gairloch, for example, associate the tree with only two things: wish-making and good luck.

The tree has therefore shed its curative properties and become a wishing tree instead, a custom much more inclusive - albeit perhaps less earnestly observed. This does not necessarily mean that by extension it has also shed its associations with Christianity. It is not explicitly stated in the literature, but the depositors could have been appealing to the saint or to God for the granting of their wishes. However, the specificity with which the tree was once affiliated with Saint Maelrubha was gradually eroded, and later pilgrims were probably 
more likely to appeal to some vague, Christian or not, wish-granting power, much like when candles are blown out on a birthday cake or a coin tossed into a fountain. McPherson describes the wishing tree as a "degenerated" custom, a "deterioration in tree worship... [which] speaks of a lingering belief and devotion" (2003 [1929]: 76). The tree has retained its sacredness as something "set apart... [for] some special purpose", although for many visitors it may no longer be considered a 'holy' site, in the Christian sense of the word.

The biography of the Isle Maree site is given in more depth by Houlbrook (2015, 2018a), while this paper explores the other coin tree sites which boast similarly lengthy biographies. Of these, three are in the Republic of Ireland (Fore, Co. Westmeath; Clonenagh, Co. Laois; Gougane Barra, Co. Cork), one in Northern Ireland (Ardboe, Co. Tyrone), and one in Wales (Patrishow, Powys).

\section{FORE, CO. WESTMEATH}

In Co. Westmeath, the Republic of Ireland, there is a small village named Fore, known in Irish as Fobhar Feichin - Feichin's Spring. It is named after St Feichin, a seventh-century saint who founded several monasteries across Ireland, including one at Fore, which was his first and largest. Because of this historical religious association, despite the village's small size, it contains several significant sites: a thirteenth-century Benedictine Priory, a fifteenthcentury anchorite's cell, and a holy well, to name but a few. It is also well-known for its 'Seven Wonders', which are listed on a large information board in the village car park: Water that will not boil, wood that will not burn, water that flows uphill, the Abbey in a quaking bog, a mill without a race, the Anchorite in a stone, and the stone raised by St Feichin's prayers.

The first two of these 'Seven Wonders' are of significance here. Water that will not boil refers to St Feichin's Well, believed to be particularly curative for toothache and headache. There is some confusion over the location of this well. In her work on Celtic sites, Elizabeth Rees describes it as a "triangular structure, its walls formed by three great stone slabs" (2003: 27), located on the path between the car park and the abbey. Elizabeth Healy, however, believes the well to be the circular stone structure in the enclosure beside the car park (2001: 71). According to Healy, the triangular structure, referred to by Rees, is actually 'St Feichin's Bath', a stone-lined vat known as the Doaghfeighin. An information plaque beside this vat describes it as follows:

Beneath an ash tree is Doaghfeighin, a box like structure built of huge stones. The name means St. Feichin's vat or keene. It is about $1.3 \mathrm{~m}$ square, and the side walls are each formed of one large stone. It is now dry but 
formerly contained water in which St. Feichin is said to have knelt in prayer. Delicate children were immersed in the water to obtain a cure through the invocation of St. Feichin.

There appear, therefore, to be two water structures associated with St Feichin: the holy well and St Feichin's vat. At some point in the last century, the well dried up, but is now marked by the stump of a tree and a young ash, which have - like the Isle Maree tree - been imbued with the well's sacredness, therefore replacing the well in pilgrims' ritual attention. Wood that will not burn apparently refers to the tree stump, and is a common description applied in Ireland to trees associated with holy wells. When this tree was still alive, it traditionally had three branches, representing the Trinity, and was - according to local belief - resistant to fire. And growing beside St Feichin's vat, still with some of its roots within the water, is a mature ash tree. All three of these have been, at some point in history, tied with rags and embedded with coins.

It is unclear when the practice of embedding coins at this site began. Photographic evidence from the 1980s shows that the original ash tree in the well now a stump - had been filled with coins by that time. It fell in the 1990s and was removed by the local council. Local resident and business owner, Jane O'Reilly, was rather cryptic when I asked where the coin-encrusted bole was removed to, assuring me that "it's somewhere safe" and adding, tongue-in-cheek, that "it wasn't burned". Even though now all that remains of this tree is a stump, on my visit there in 2012 it still contained two coins, both of which must have been inserted since the tree fell, for they date to 1999 and 2006.

Growing above this stump and concealing it is the young ash tree, which was planted by the local council following the fall of the original and was intended as a replacement (Fig. 2). Today it is still customary to leave offerings at the tree. Affixed to its branches are all manner of objects: strips of fabric, socks, gloves, hair bobbles and clips, bra straps, key chains, baby's bibs, stockings, handkerchiefs, shoelaces, scarves, belts, pieces of string, sweet and crisp wrappers, a piece of tin foil, shoes, earrings, and a toothbrush, to name only some examples.

Similarly, the living tree growing beside St Feichin's vat has been adorned with a vast and seemingly random collection of objects: strips of fabric, socks, gloves, hair bobbles and clips, key rings, teddy bears, shoes, scarves, earrings, bracelets, a watch, a lighter, shoelaces, belts, rosary beads, pieces of string, a coat hanger, baby's bibs, stockings, sweet and crisp wrappers, bra straps, handkerchiefs, trainers, a broken umbrella, a Primark clothes label, a bridal veil - even insurance documents and a boarding pass from Latvia attached to the tree in a plastic wallet. 


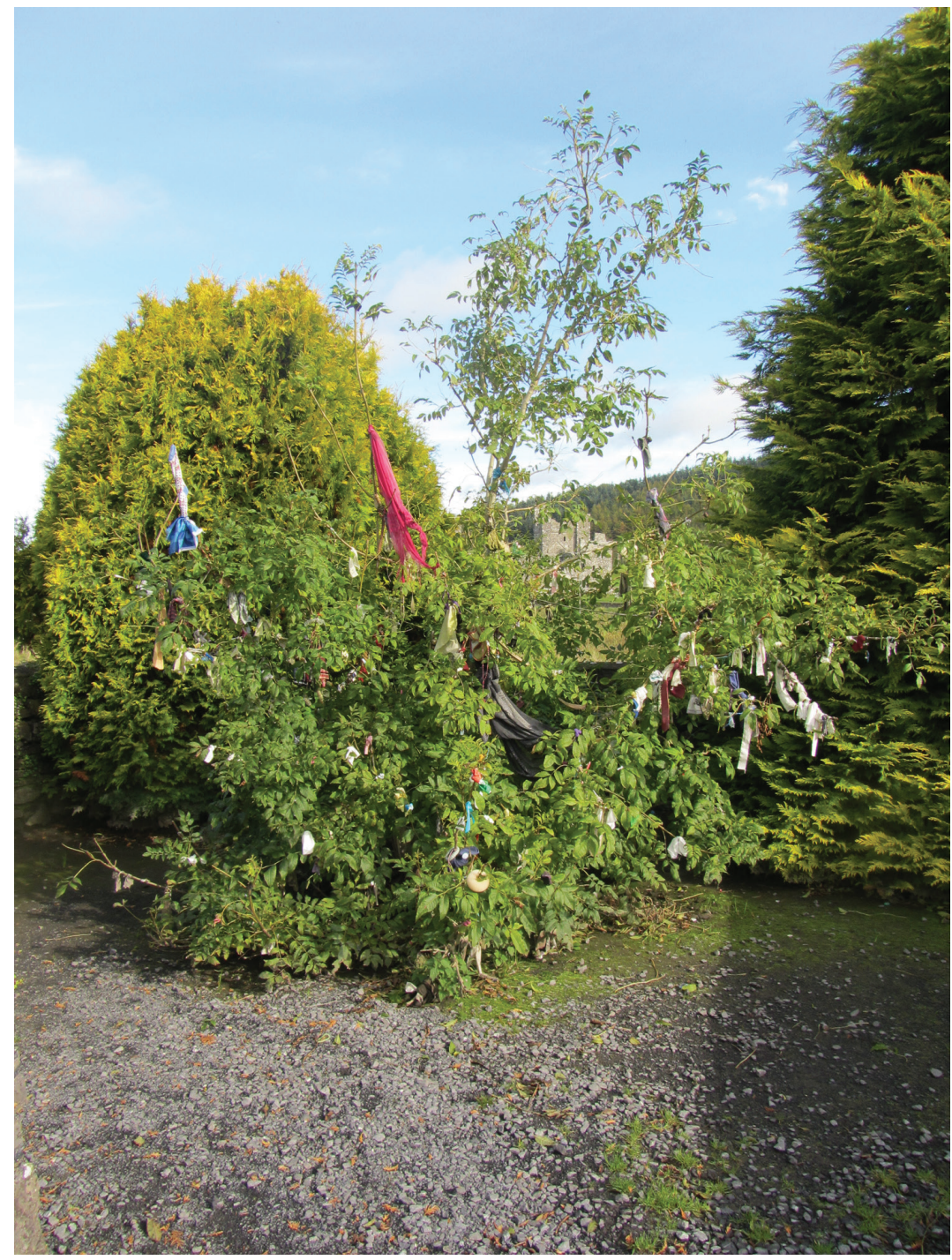

Figure 2. The rag tree sitting on the site of St Feichin's holy well, now dried up. Fore, Co. Westmeath, Republic of Ireland. Photograph by the author, 3 October 2012.

The two living trees have thus replaced the original, a method of substitution that is certainly not atypical. In many cases, one tree dies and another is adopted. Hartland, appearing rather disapproving of this process, notes that "the reason for the sacredness of many trees or wells has passed from memory; and it has consequently been natural to substitute any tree or any well for a particular one" (1893: 469-470). In some cases, depositors have had to be quite imaginative. For example, at Doon Well, Co. Donegal, which was resorted 
to for cures during the nineteenth century, a nearby hazel was used as a rag tree. This tree eventually became too heavily adorned with rags to admit new additions, but the well was situated in a largely treeless landscape, so there was no convenient replacement. In answer to this problem, people began embedding crutches (a popular deposit indicating a successful cure) into the ground beside the well, and subsequent visitors began attaching their rags to these instead. More often than not though, young trees replace old trees, a method of substitution that we will see repeated below.

\section{CLONENAGH, CO. LAOIS}

Less than 100 miles south of Fore is another site with a similar history: Clonenagh, Co. Laois. Perched on a grassy bank a few metres to the side of the R445, a busy road running between Dublin and Limerick, is a young sycamore. Close by is an interpretation panel set up by Laois County Council, which offers the following information about what it dubs "St Fintan's Tree":

This tree was planted 200 to 250 years ago, within the area of the ancient Monastery of Clonenagh.

A well which also venerated the Saint was nearby. When the well was closed, a spring appeared in the fork of the tree and became the focal point for "patterns" (celebrations on the Saint's feast day) for many years.

A custom developed of inserting coins into the bark of the tree, and it became known as the "Money Tree". Because of metallic poisoning and damage to the bark due to this custom, the tree has now gone into decay. But a number of shoots have been salvaged and it is hoped that these might prolong the life of the tree.

Please refrain from inserting any metal into the tree or damaging it in any way.

Saint Fintan pray for us.

This information plaque clearly demonstrates a firm connection between the tree and St Fintan, a sixth-seventh-century Irish saint who is believed to have founded the monastic community of Clonenagh (Sperber 2004: 29-30). According to local historian Roe, writing in the 1930s, there was once a "fine spring well" nearby, which was "always the subject of great veneration among the country people" (1939: 27). This veneration continued until the mid-nineteenth century, until it was filled in by the landowner, a Protestant farmer who was "annoyed by the number of people who visited this well" (ibid.). According to local legend, St Fintan subsequently diverted this spring from the farmer's 
land to a hollow in the nearby sycamore tree, St Fintan's Tree, which became known as the "Well in the tree" (Morton 2004 [1998]: 195), through the process of sacred transference, as outlined above.

The veneration awarded to the Clonenagh tree led to its employment as a rag tree. People made wishes with the water from the well and then tied a rag or ribbon to the tree's branches. A photograph taken by Father Francis Browne in 1933 shows a priest sitting in the branches surrounding this hollow, possibly having just made an offering of his own (Harbison 1991: Fig. 102). It is unclear when rags were replaced by coins, but it must have occurred between the 1930s - no coins are visible in Father Browne's photograph of the tree and the $1990 \mathrm{~s}$, for at the time Harbison was writing his work on pilgrimage in Ireland in 1991, there were apparently "thousands of coins hammered into the tree by passers-by" (1991: 231). When the tree died and fell in 1994, the practice of coin insertion had become so prolific that the tree is described as having been densely embedded with coins to a height of two metres (Simon 2000: 28). This tree-encrusted bole has since been removed, but (despite the appeal to the contrary in the interpretation panel: "Please refrain from inserting any metal into the tree or damaging it in any way") people have begun embedding coins into the young offshoot, which grows on the same site.

\section{GOUGANE BARRA, CO. CORK}

Gougane Barra is a lakeside settlement in Co. Cork, named for sixth-century St Finbarr, who is believed to have built a monastery on an island in the lake. This island, which is connected to land by a causeway, also contains eighteenthcentury ruins from a priest's retreat, a nineteenth-century oratory, and several coin trees. Although these trees do not appear to have any significant history, unlike those above, the island of Gougane Barra has long been the site of both pilgrimage and ritual deposition, its remote location making it a prominent site for rituals which combined Christianity with pagan practices (McCarthy 2006: 21).

Throughout the eighteenth and nineteenth centuries, several hundred pilgrims would flock annually to the island of Gougane Barra for the Eve of St John's feast, a pilgrimage described by Irish folklorist Thomas Crofton Croker, who partook in the celebrations there in 1813. He recounted the following scenes:

It was not without difficulty that we forced our way through the crowd on the shore of the lake, to the wall of the chapels on the island, where we stood amid an immense concourse of people: the interior of the cells were 
filled with men and women in various acts of devotion, almost all of them on their knees; some, with hands uplifted, prayed in loud voices, using considerable gesticulation, and others, in a less noisy manner, rapidly counted the beads of their rosary, or, as it is called by the Irish peasant, their pathereen, with much apparent fervour... Adjoining the causeway, part of the water of the lake was inclosed and covered in as well, by which name it was distinguished... Within, the well was crowded to excess, probably seven or eight persons, some with their arms, some with their legs thrust down into the water, exhibiting the most disgusting sores and shocking infirmities. When those within came out, their places were as instantly filled by others. Some there were who had waited two or three hours before they could obtain access to this "healing fount." The blind, the cripple, and the infirm jostled and retarded each other in their efforts to approach; whilst women and boys forced their way about, offering the polluted water of the well for sale, in little glass bottles, the bottom of broken jugs and scallop shells, to those who strength did not permit them to gain this sacred spot... (1968 [1824]: 277ff.)

Croker proceeds to give a detailed account of the excessive drinking and nightlong dancing which invariably followed these rites. He does not reference any custom involving a tree, but does refer to a wooden pole standing in the centre of the Pilgrim's Terrace; this was apparently all that remained of a large cross which once stood there. Croker describes the popular custom of attaching votive rags and bandages to this wooden pole, "by those whose faith has made them whole, intended as acknowledgments of their cure". These rags and bandages were affixed to the pole by nails, causing it also to be "braced with many pieces of iron" (1968 [1824]: 276-277).

These were banned as being 'pagan' by the Catholic Bishop of Cork, John Murphy, in 1818 (McCarthy 2006: 21). However, this does not appear to have deterred pilgrims from attaching their offerings to the wooden post in the Pilgrim's Terrace, and then to the replacement wooden cross that was commissioned by the parish priest in the early 1900s. By this time, the rags and "many pieces of iron" seem to have been replaced by coins, and as the cross became too densely embedded, people turned to the ash tree that stood in the main cell's enclosure - which fell in a storm in 1973 and its remains were removed. But the custom continued; seven other trees scattered across the small island are currently being embedded with coins. 


\section{ARDBOE, CO. TYRONE}

Over the border, in Northern Ireland, is another historic site which houses a coin tree. Ardboe, Co. Tyrone, has hosted two trees of cultural significance, one replacing the other. The original, known locally as the 'wishing tree' or the 'pin tree', was one of several beech trees standing within the Old Cross graveyard, in close vicinity to Ardboe High Cross, the tallest cross in Northern Ireland. The original tree had probably been planted in the mid-nineteenth century by local resident Christopher Treanor. It is both possible, although difficult to prove, that it was planted to replace an earlier healing or wishing tree, and that it was planted on the site of a former holy well (and thus became the centre of ritual attention through the process of sacred transference), both theories proposed by local historian and author Pat Grimes (2000).

This coin tree was initially a rag tree. Mr C. D. Deane, the former Deputy Director of Belfast Museum and Art Gallery, was quoted in the Mid-Ulster Mail in 1959 as describing the coin tree as having been originally adorned with rags, which "were not merely offerings, they were riddances, the putting away of the evils impending or incurred by sin or sickness" (1959). Deane also describes how rainwater would collect in a hole in the tree, in which the sick would bathe their faces hoping for cures (ibid.). This is reminiscent of the Clonenagh sycamore, above.

By the 1940s, local tradition held that warts and lumps could be cured by pricking them with a pin and then inserting that pin into the tree, but many other objects were also inserted. Francis Quinn, caretaker of the Old Cross of Ardboe - and consequently also the tree-describes the site: the "tree, filled with pins, pennies, nails, buttons, and such things, is called the wishing tree or pin tree. It was there in my father's and grandfather's time. Everybody that comes here puts in a pin or a nail or any such thing and makes a wish" (Devlin 1948).

Eight years later, in an article in the Mid-Ulster Observer, Quinn was interviewed again concerning this tree: "When asked if the wishes came true, Francis only smiled and declared that he did not know. He did add that young girls often wished for a husband but he had never heard tell of the tree proving obliging in this respect" (Anonymous 1956: 3). Three years later, when Deane's talk on the Old Cross of Ardboe was broadcast (1959), he described how "the bark is stained with the rust of a thousand pieces of metal: hairpins, safety-pins, pennies, nails, bolts, and even a military badge, the personal offerings of a wishful public".

This tree fell in the winter of 1973-1974, and as local resident Pat Grimes writes, "[a]lmost immediately visitors and pilgrims to Ardboe began to use an adjacent mature beech tree as a repository for their coins, pins, and wishes" (1999). However, this substitute tree fell during a storm on Christmas Eve, 
1997, and although another replacement was planted in 1998 (ibid.), it has not yet been subject to ritual deposition, probably because it is still too small. Coin-encrusted segments of the original fallen tree survive though: one stored in a garage behind Coyle's Cottage, the home of the Muintirevlin Historical Society; another contained within a cardboard box and held in store at the Ulster Folk and Transport Museum (Accession Number 346-1998); and another being used as a coffee table by a local resident.

\section{PATRISHOW, POWYS}

The Patrishow coin tree stands close to the holy well of St Issui. The life of this saint is little known, but he is often described as a holy man living a secluded life in a hermit cell beside Nant Mair, or Mary's Brook. Close by was his well, containing niches in which offerings could be left (Figs. 3-4). Legend tells of a French pilgrim whose leprosy was cured by this well; in gratitude, he left a sack of gold, which was used to build the earliest part of the nearby eleventhcentury church (Baring-Gould \& Fisher 1911: 321-323; Jones, F. 1954: 145; Pemberton 1999: 190; Jones, A. 2002: 68-69).

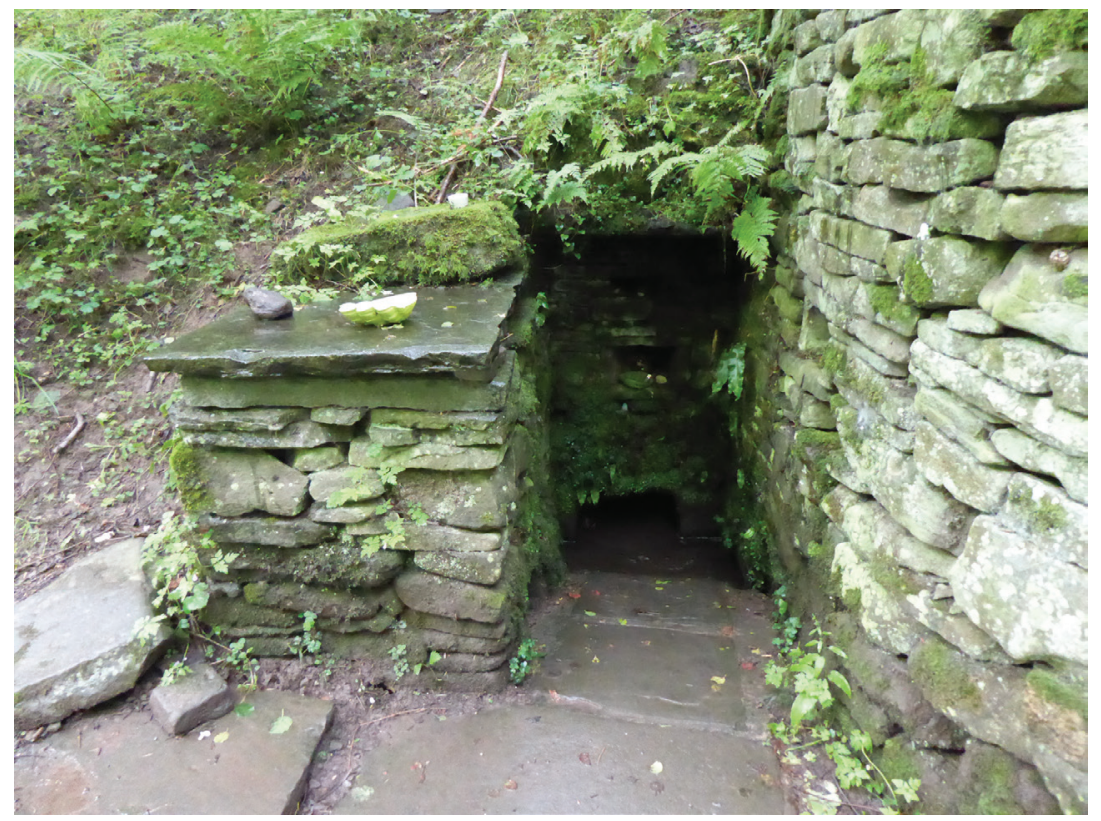

Figure 3. The holy well of St Issui, Patrishow, Powys, Wales, surrounded by niches for offerings. Photograph by the author, 22 July 2017. 


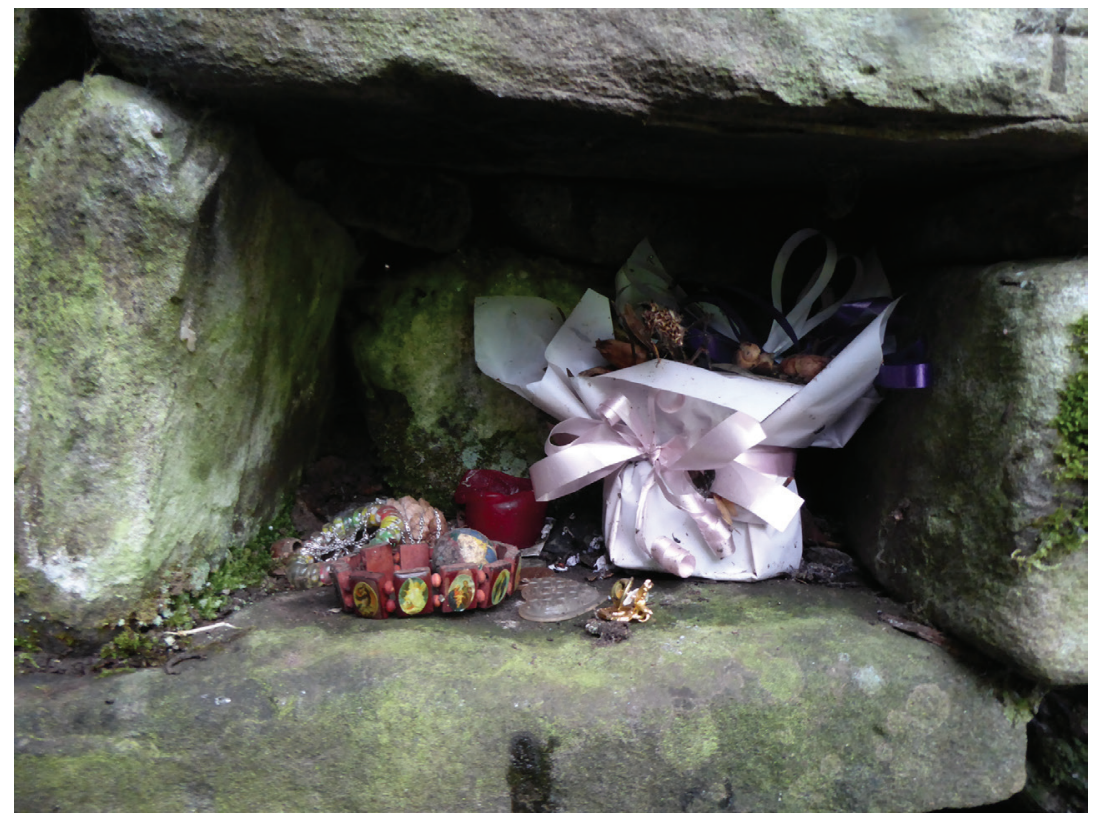

Figure 4. One of the niches containing offerings at the holy well at Patrishow. Photograph by the author, 22 July 2017.

The well that occupies the site now is probably an eighteenth- or nineteenthcentury rebuild (Jones, A. 2002: 68; De Waal 2011: 73). Fed by a shallow spring, the well is surrounded on three sides by stone walls and covered by a stone slab. In 1804, Welsh topographer Richard Fenton described it as "a very scanty oozing of water, to which, however, was formerly attributed great Virtue, as within the building that encloses it are little Niches to hold the Vessels they drank out of and the offerings they left behind" (Fenton 1917: 26). By the nineteenth century, therefore, this site was still a place of ritual deposition, and indeed it continued to be one throughout the twentieth and into the twenty-first. A photograph in Siân Victory's The Celtic Church in Wales shows how the well still contained niches for offerings in the 1970s (1977: Plate IV (a)). And on my visit to the site in 2017, there was a vast variety of objects deposited around the well, from candles and makeshift crosses to jewellery, semi-precious stones, and children's toys.

There was also, a few feet away, a tree encrusted with coins (Fig. 5). We might assume then that this is another historic coin tree, akin to those explored above, in Ireland and on Isle Maree. However, this coin tree does not seem to share the well's antiquity. None of the identified sources describing ritual deposition at the site, which range in date from 1804 to 2011, mention a tree (Fenton 
Figure 5. The tree standing beside the holy well at Patrishow, embedded with coins and bedecked with rags, ribbons, and other offerings. Photograph by the author, 22 July 2017.

1917; Jones, F. 1954; De Waal 2011). Granted, an absence of evidence is not necessarily evidence of absence, but none of the coins embedded into the Patrishow tree appeared to be predecimal. In fact, many of them were new, one at least dating as recently as 2017. The likeliest explanation

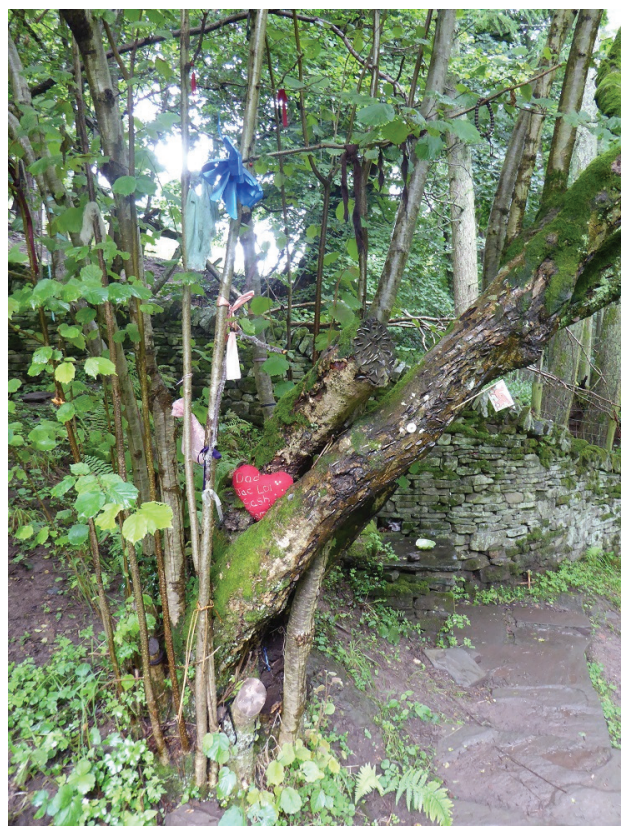
therefore is that the spread of attention from the well to the tree is recent, probably contemporary with the late twentieth / early twenty-first-century rise of the coin tree custom (Houlbrook 2018a).

If this site follows the patterns of others, then it is possible - probable even that the coin tree will eventually replace the holy well through the process of sacred transference. The well might dry up, both in terms of its supply of water, already described by Fenton in 1804 (published in 1917) as "a very scanty oozing", and in terms of its religious relevance. The holy wells of Isle Maree, Fore, Clonenagh, and possibly Ardboe, have disappeared now, leaving trees in their stead, while the trees at Gougane Barra replace a large wooden cross. The sites may still be associated with Christianity, but modern-day visitors appear more inclined to participate in a custom with fewer religious overtones: they hammer coins into trees to make wishes rather than drink water from walls to effect cures and offer votive rags to their presiding saints.

\section{CONCLUSION}

The sanctity of these Scottish, Irish, and Welsh sites has been sustained, surviving centuries. However, they have certainly not remained static for all this time. With the loosening grip of the Church and the declining faith in the power of saints and their holy wells, the traditions needed to adapt in order to retain their 
popularity. Thus, these sites are now largely employed for wish-granting, evidently a more popular and inclusive practice than appealing to Christian saints for remedies to ailments. This transition is reflected in the biographies of the sites.

Holy wells become desecrated, dry up, or simply fall out of use, and sanctity and thus ritual attention - is transferred to nearby trees, which can sometimes become 'holy wells' in and of themselves. They are transformed from altars of convenience to rag trees; from rag trees to nail or pin trees; and then to coin trees. As one tree falls - literally - another is adopted as replacement; the sacred is substituted and therefore sustained. By tracing the history of these sites, it becomes clear that just as a natural site changes over time, through both organic processes and human intervention, the 'sacred' is equally malleable. Both lend themselves to adaptation, making them not only compatible with each other, but perpetually relevant to contemporary society. They are both mutable, ambiguous, and - like everything else - they must adapt in order to survive.

\section{REFERENCES}

Anonymous 1956. Interview with Francis Quinn. Mid-Ulster Observer, 29 November, p. 3. Baring-Gould, Sabine \& Fisher, John 1911. The Lives of the British Saints: The Saints of Wales and Cornwall and Such Irish Saints as Have Dedications in Britain. In 4 volumes. Volume 3. London: The Honourable Society of Cymmrodorion. Available at https://archive.org/details/livesofbritishsa03bariuoft/page/n3/mode/2up, last accessed on 11 December 2020.

Barnett, Thomas Ratcliffe 1930. Autumns in Skye, Ross \& Sutherland. Edinburgh: John Grant Booksellers Ltd.

Bord, Janet \& Bord, Colin 1985. Sacred Wells: Holy Wells and Water Lore in Britain and Ireland. London: Paladin Books.

Campbell, John Francis 1860. Popular Tales of the West Highlands. Vol. 2. Edinburgh: Edmonston and Douglas. Available at https://deriv.nls.uk/ dcn6/8141/81417071.6.pdf, last accessed on 8 December 2020.

Croker, Thomas Crofton 1968 [1824]. Researches in the South of Ireland, Illustrative of the Scenery, Architectural Remains and the Manners and Superstitions of the Peasantry, with an Appendix Containing a Private Narrative of the Rebellion of 1798. Shannon: Irish University Press.

De Waal, Esther 2011. Living on the Border: Reflections on the Experience of Threshold. Norwich: Canterbury Press.

Deane, C. D. 1959. Broadcast Talk on the Old Cross of Ardboe. Mid-Ulster Mail, 23 May.

Devlin, Henry 1948. Collected History of Ardboe. Collected in the summer of 1948 from the parish of Ardboe, Co Tyrone. Manuscript.

Dixon, John H. 1984 [1886]. Gairlock in North-West Ross-shire: Its Records, Traditions, Inhabitants, and Natural History with a Guide to Gairlock and Loch Maree and a Map of Illustrations. 4th reprint. Fort William: Nevisprint Ltd. 
Duff, David (ed.) 1968. Victoria in the Highlands: The Personal Journal of Her Majesty Queen Victoria: with Notes and Introductions, and a Description of the Acquisition and Rebuilding of Balmoral Castle. London: Frederick Muller Ltd.

Fenton, Richard 1917. Tours in Wales (1804-1813). Ed. by John Fisher. London: Bedford Press.

Godden, Gertrude M. 1893. The Sanctuary of Mourie. Folklore, Vol. 4, No. 4, pp. 498-508. http://dx.doi.org/10.1080/0015587X.1893.9720183.

Grimes, Pat 1999. The Pin Tree. Loughshore News, March.

Grimes, Pat 2000. Muintirevlin Remembers: The History of the People around the Old Cross. Ardboe: Muintirevlin Historical Society.

Harbison, Peter 1991. Pilgrimage in Ireland: The Monuments and the People. Syracuse: Syracuse University Press.

Hartland, E. Sidney 1893. Pin-Wells and Rag-Bushes. Folklore, Vol. 4, No. 4, pp. 451-470. http://dx.doi.org/10.1080/0015587X.1893.9720181.

Healy, Elizabeth 2001. In Search of Ireland's Holy Wells. Dublin: Wolfhound Press Ltd.

Hope, Robert Charles 1893. The Legendary Lore of the Holy Wells of England: Including Rivers, Lakes, Fountains, and Springs. London: Elliot Stock.

Houlbrook, Ceri 2014. The Mutability of Meaning: Contextualizing the Cumbrian Coin-tree. Folklore, Vol. 125, No. 1, pp. 40-59. http://dx.doi.org/10.1080/001558 7X.2013.837316.

Houlbrook, Ceri 2015. The Wishing-Tree of Isle Maree: The Evolution of a Scottish Folkloric Practice. In: C. Houlbrook \& N. Armitage (eds.) The Materiality of Magic: An Artefactual Investigation into Ritual Practices and Popular Beliefs. Oxford \& Philadelphia: Oxbow Books, pp. 123-142.

Houlbrook, Ceri 2018a. The Magic of Coin-trees from Religion to Recreation: The Roots of a Ritual. Palgrave Macmillan.

Houlbrook, Ceri 2018b. Why Money Does Grow on Trees: The British Coin-tree Custom. In: M.N. Burström \& T.G. Ingvardson (eds.) Divina Moneta: Coins in Religion and Ritual. Oxon \& New York: Routledge, pp. 87-107.

Hull, Eleanor 1928. Folklore of the British Isles. London: Methuen \& Co. Ltd.

Jones, Francis 1954. The Holy Wells of Wales. Cardiff: University of Wales Press.

Jones, Andrew 2002. Every Pilgrim's Guide to Celtic Britain and Ireland. Norwich: Canterbury Press.

Lucas, A. T. 1963. The Sacred Trees of Ireland. Journal of the Cork Historical and Archaeological Society, Vol. 68, Nos. 207-208, pp. 16-54. Available at https:// www.corkhist.ie/wp-content/uploads/jfiles/1963/b1963-002.pdf, last accessed on 8 December 2020.

MacLeish, Kenneth 1968. The Highlands of Scotland. National Geographic, Vol. 133, No. 3, pp.398-435.

Macrow, Brenda G. 1953. Torridon Highlands. London: Robert Hale \& Company.

McCarthy, Kieran 2006. In the Steps of St Finbarre: Voices and Memories of the Lee Valley. Dublin: Nonsuch Publishing.

McPherson, Joseph M. 2003 [1929]. Primitive Beliefs in the Northeast of Scotland. Whitefish, Montana: Kessinger Publishing Co. 
Mitchell, Arthur 1860-1862. On Various Superstitions in the North-West Highlands and Islands of Scotland, Especially in Relation to Lunacy. Proceedings of the Society of Antiquaries of Scotland, Vol. 4, pp. 251-288. Available at https:// archaeologydataservice.ac.uk/archiveDS/archiveDownload?t=arch-352-1/ dissemination/pdf/vol_004/4_251_288.pdf, last accessed on 8 December 2020.

Morton, Andrew 2004 [1998]. Tree Heritage of Britain and Ireland: A Guide to the Famous Trees of Britain and Ireland. Marlborough: Airlife Publishing.

OED 2019a = 'holy, adj. and n.'. Oxford English Dictionary. http://www.oed.com.ezproxy. herts.ac.uk/view/Entry/87833?rskey=nyGGTd\&result=1\&isAdvanced=false\#eid, last accessed on 8 February 2019.

OED 2019b = 'sacred, adj. and n.'. Oxford English Dictionary. http://www.oed.com. ezproxy.herts.ac.uk/view/Entry/169556?rskey=adXNfo\&result=3\&isAdvanced= false\#eid, last accessed on 8 February 2019.

Pemberton, Cintra 1999. Soulfaring: Celtic Pilgrimage Then and Now. Harrisburg, PA: Morehouse Publishing.

Pennant, Thomas 1775. A Tour in Scotland, and Voyage to the Hebrides, MDCCLXXII. Vol. 2. Dublin: A. Leathley.

Rackard, Anna \& O'Callaghan, Liam \& Joyce, David 2001. Fish Stone Water: Holy Wells of Ireland. Cork: Cork University Press.

Rees, Elizabeth 2003. An Essential Guide to Celtic Sites and Their Saints. London \& New York: Burns \& Oates.

Reeves, William 1857-1859. Saint Maelrubha: His History and Churches. Proceedings of the Society of Antiquaries of Scotland, Vol. 3, pp. 258-296. Available at https://archaeologydataservice.ac.uk/archiveDS/archiveDownload?t=arch-352-1/ dissemination/pdf/vol_003/3_258_296.pdf, last accessed on 7 December 2020.

Roe, Helen M. 1939. Tales, Customs and Beliefs from Laoighis. Béaloideas, Vol. 9, No. 1, pp. 21-35. http://dx.doi.org/10.2307/20642522.

Shepherd, Val 1994. Historic Wells in and around Bradford. Loughborough: Heart of Albion Press.

Simon, Ben 2000. Tree Traditions and Folklore from Northeast Ireland. Arboricultural Journal, Vol. 24, No. 1, pp. 15-40. http://dx.doi.org/10.1080/03071375.2000.974 7260 .

Sperber, Ingrid 2004. 'Late and Not of Special Distinction'? The Misunderstood Life of St Fintan of Clonenagh. Ossory, Laois and Leinster, Vol. 1, pp. 28-49.

Victory, Siân 1977. The Celtic Church in Wales. London: SPCK.

Ceri Houlbrook is a Lecturer in Folklore and History at the University of Hertfordshire, United Kingdom. Her primary research interests are contemporary rituals and beliefs, and the material culture of folklore. She has published a monograph on coin-trees, The Roots of a Ritual, and on the contemporary love-lock, Unlocking the Love-Lock.

c.houlbrook@herts.ac.uk 